\title{
Borehole Drying: A Review of the Situation in the Voltaian Hydrogeological System in Ghana
}

\author{
John Apambilla AKUDAGO ${ }^{1}$, Larry Pax CHEGBELEH ${ }^{1}$, Makoto NISHIGAKI ${ }^{2}$, \\ Nukunu A NANEDO ${ }^{3}$, Anthony EWUSI ${ }^{4}$, Kwabena KANKAM-YEBOAH \\ ${ }^{1}$ Graduate School of Environmental Science, Okayama University, Okayama, Japan \\ ${ }^{2}$ Faculty of Environmental Science, Okayama University, Okayama, Japan \\ ${ }^{3}$ Research and development Manager, World Vision Ghana Rural Water Project, Tamale, Ghana \\ ${ }^{4}$ Geological Engineering, University of Mines and Technology, Tarkwa, Ghana \\ ${ }^{5}$ CSIR Water Research Institute, P.O. Box M.32, Accra, Ghana \\ E-mail: jaakud@yahoo.com \\ Received May 29, 2009; revised July 4, 2009; accepted July 9, 2009
}

\begin{abstract}
Groundwater development for potable water supply for rural people in Africa especially in Ghana has increased significantly over the past decades. The area underlain by the Paleozoic sedimentary formation (Voltaian System) of the country in particular, has experienced this tremendous change. Groundwater in the study area is normally exploited through boreholes fitted mostly with hand pumps. Though the boreholes exhibit variable yields, most of them have yields greater than $13.5 \mathrm{l} / \mathrm{min}$. Research carried out in the area suggests that there is modern and enough recharge, yet borehole drying is a problem especially those with low or marginal yields. A thorough review of the groundwater exploitation in the area, aimed at explaining the circumstances that might lead to these phenomena on the field, has been conducted. The review shows that boreholes with drill yields of usually $<20 \mathrm{l} / \mathrm{min}$, especially those drilled in the wet season, constitute the highest percentage of the dried boreholes. Other construction material such as the filter media may also influence the drying process.
\end{abstract}

Keywords: Borehole Sustainability, Community Water Supply, Ghana, Groundwater Recharge and Depletion, Voltaian System

\section{Introduction}

The demand for potable water has been increasing since the last three decades due to increasing world population growth. The main sources of water to match these demands include surface waters (from rivers, lakes, streams, ponds) and groundwater. In arid to semi-arid environments, temperatures are usually high and this eventually results in high evaporation rates. Some researchers have reported that surface water bodies that provide water for use especially for irrigation have experienced recent reduction in volume and quality [1,2]. The location and occurrence of surface water make them very susceptible to pollution. Supplying water from these sources especially for domestic purposes require treatment which could be very expensive especially in small settlement communities or towns. In poverty stricken environments, people try to use these waters as they exist, resulting in outbreaks of water borne diseases.

Groundwater which occurs below the surface in the soil pores, fractures, fissures and other weak geological features or zones is relatively protected from bacteriological contamination and evaporation and can be used for domestic and industrial water supply. The ease of tapping the resource at very close point of need gives it an added advantage over surface waters. These merits have caused people to heavily rely on groundwater for domestic, agricultural and industrial purposes.

Groundwater is usually exploited from drilled boreholes, hand-dug wells or spring sources. The latter is usually scarce in many flat or high altitude areas except where the groundwater table rises above the ground surface. Water supply from this type of source is relatively meagre. However, boreholes and hand-dug wells have 
become the most popular way of supplying groundwater to people in small communities.

It has been reported that about 1.5 billion people worldwide depend on groundwater daily [3]. In Africa, groundwater has proved to be very useful especially for rural water supply for the $47 \%$ of the people with access to potable water [4-6]. In this regard, it has been reported that about 250,000 boreholes have been constructed for use in Africa [7]. Though the purpose of these initiatives is to afford sustainable water supply in terms of quality and quantity, there are many reports of abandonment of some of these facilities in many places [6-11]. The reasons assigned to the abandonment include the mechanical breakdown of hand pumps and lack of water in the borehole. It has been reported that hand pumps were observed to be nonfunctional in some communities in Mali where some women preferred to fetch water from shallow hand-dug wells and surface water sources [6]. With availability of modern technology, hand pumps have now been made simple and maintenance could be carried out at the community level where breakdown is no longer a major problem. However, lack of water in the borehole could result from many sources such as lowering of groundwater table and depletion of aquifer storage, improper borehole design and defects from construction, clogging of the filter media and the slots of the screen pipes.

Lowering of groundwater levels and depletion of aquifer storage could arise when there is excessive pumping compared with recharge [12-15]. Excessive pumping could cause intrusion of saline water into fresh aquifers to maintain groundwater levels in coastal areas. On the other hand, if there is improper design or defects in the construction of boreholes the aquifer zones could be sealed. There have been reported cases of situation in some boreholes in Ghana up to $18 \mathrm{~m}$ due to broken screen pipes [16]. Consequently, the aquifers are blocked from transmitting water to the boreholes. As reported in literature, water of turbidity greater than 30 NTU causes rapid clogging [17] especially in cases where improper filter media has been used to construct the borehole.

Boreholes fitted with hand pumps are the main sources of potable water supply for rural communities in Ghana. Though the effort for providing potable water is to mitigate high water related diseases in many rural areas especially in the drought prone northern and eastern parts of the country, drying of some boreholes have been reported in some geological formations $[18,19]$. One of such formations is the Voltaian System which is believed to be late Proterozoic to early Palaeozoic in age [20] and underlain by consolidated sedimentary rocks. Recharge studies conducted using various techniques such as isotopic $[19,21]$ and numerical models have shown that there is fresh and enough recharge to groundwater $[22,23]$. However, a lot of marginal or low yielding (usually far less than $100 \mathrm{l} / \mathrm{min}$ ) boreholes dry up especially in the study area after 1- 4 years of usage or less.

In this paper, a review of the borehole drying situation especially in the Voltaian System of Ghana has been carried out to understand the possible causes of it. The review also tends to explain the reasons why redevelopment of some clogged boreholes have not been effective.

\section{Study Area}

The Voltaian System which cuts across many parts of Ghana, and extends to the Republic of Togo, is the main area where the country depends for its food production. It lies between latitude $11^{\circ} \mathrm{N}$ and $6^{\circ} \mathrm{N}$ and Longitude $1^{\circ} \mathrm{E}$ and $2^{\circ} \mathrm{W}$. The topography of the area is gently undulating in the southern part whereas the northern portion is fairly flat. Close to the geological boundaries, there exist steep hills up to about $450 \mathrm{~m}$ high in the north and $200-300 \mathrm{~m}$ high in the south. All the hills trend in the north-east south-west direction. The annual rainfall in the Voltaian Basin ranges from $750 \mathrm{~mm}$ in the north to $1600 \mathrm{~mm}$ in the south, with evapo-transpiration averaging around 890 $\mathrm{mm}$ [24].

Drainage in the study area is enhanced by the Black and White Voltas and the Oti Rivers, and finally flows into the Volta Basin. However, there are smaller rivers which drain into these main rivers. The vegetation in the Voltaian System is wooden savannah in the north and moist deciduous forest in the south. The vegetation in the northern part of the System consists of the savannah plants mainly dense annual and perennial grass, bushes and trees.

The study area is the region with the least percentage of people having access to potable water supply and contributes the highest cases of guinea worm infection and other water borne diseases in Ghana.

\section{Geology and Hydrogeology}

The Voltaian System occupies about $40 \%$ of the entire land area of Ghana (Figure 1) and it is thought to be about 3000 - 4000m thick. It covers most of the northern part of Ghana. In most of these places surface waters flows are ephemeral, occurring only during the wet season. The System consists of inter-bedded rocks including mudstones, sandstones, arkose, conglomerate, shale, and some limestone. The rocks are flat lying or gently dipping except near the eastern margin of the basin adjacent to the contact with the Precambrian rocks where the lower members of the System are gently folded [25]. They are generally consolidated and are not inherently permeable. Possible exceptions, however, do exist in areas where the jointed sandstones, arkoses and quartzite upon weathering have produced permeable surficial materials. Again, the rocks have undergone some degree of 


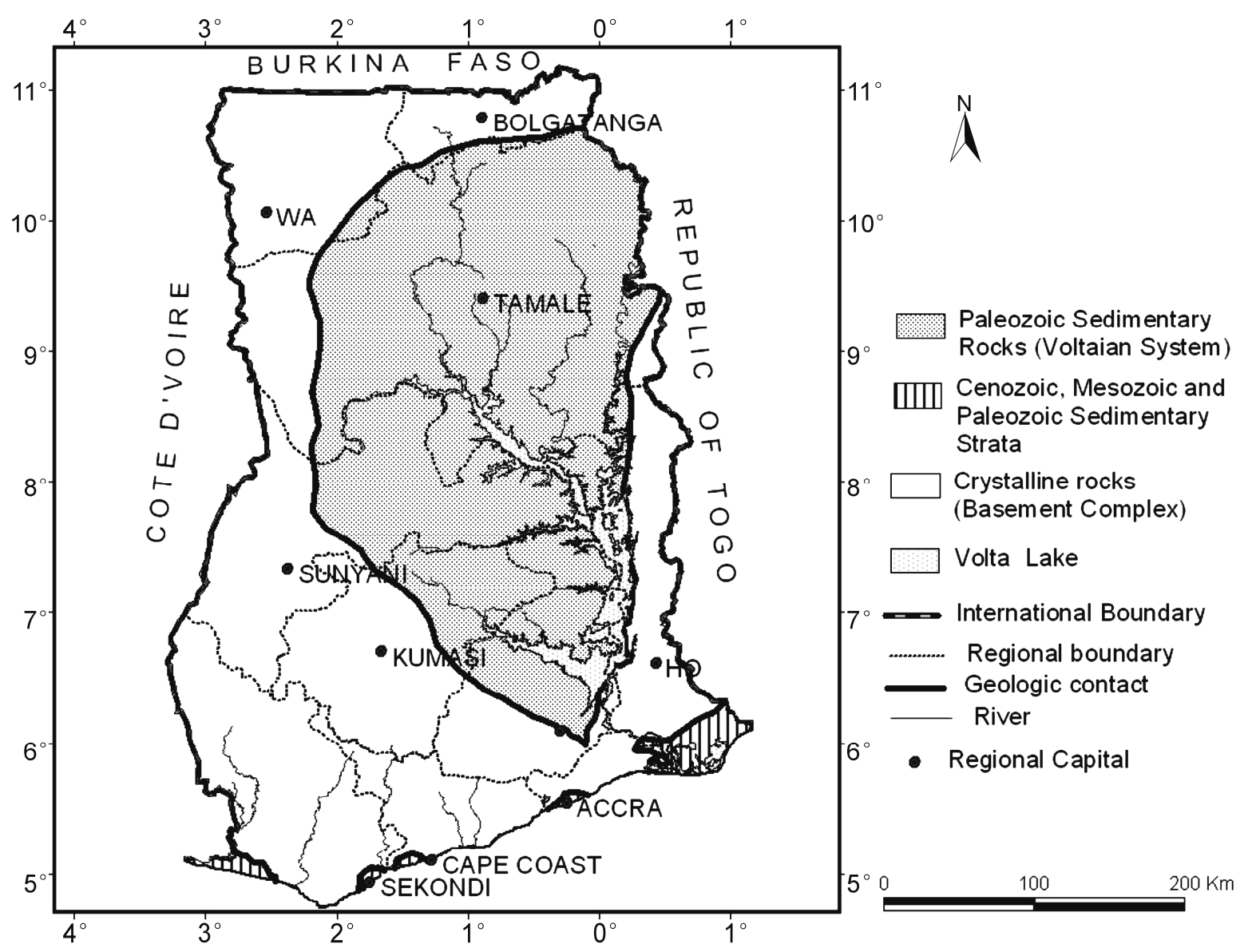

Figure 1. Geological map of the study area (modified after Dapah-Siakwan and Gyau-Boakye, 2000).

tectonic activity and most aquifers are made up of fractures. However, there exist unconsolidated systems dotted in many parts of the basin where good aquifers have been located.

Available records show that for most of the areas maximum borehole depth is about $90 \mathrm{~m}$ with an average depth of 48.1m [26]. However, there is report of a few boreholes exceeding $100 \mathrm{~m}$, even up to about $150 \mathrm{~m}$ deep in the far eastern part of the System [19]. Generally, the Voltaian has very poor groundwater potential although some water supplies come from fractures in the argillaceous or loose zones in the arenaceous members [27]. In some portions of the southern part of the Voltaian basin, the weathered or loose zones range from 4 to $20 \mathrm{~m}$ thick where many villagers rely on for hand dug borehole development [18,28]. Borehole yields range from 5 to 1200 $\mathrm{l} / \mathrm{min}$, static water levels from 1 to $20 \mathrm{~m}$ and water table fluctuation averaging about $4 \mathrm{~m}[21,29,30]$. The estimated transmissivities range from 0.3 to $270 \mathrm{~m}^{2} /$ day [29]. Most of the aquifers are semi-confined to confined and groundwater quality conforms to the World Health Organization standards. However, there have been few cases of high arsenic and fluoride levels in some drilled boreholes [7,23,31]. Groundwater salinity has also been a major challenge especially in the south-eastern and north-western parts of the basin.

Groundwater recharge varies from location to location, depending on the infiltration capacity of the surface and the permeability of adjacent geologic material shielding the aquifer. Available literature indicates that groundwater recharge in the Voltaian ranges from $3.7-5 \%$ of annual rainfall $[22,32,33]$ and groundwater abstraction is estimated to be less than $5 \%$ of the annual groundwater recharge $[22,23]$.

\section{History of Groundwater Development in the Voltaian}

Drilling of boreholes in the Voltaian System began far back in the 1940s [24]. However, the few holes which were drilled did not show good results resulting in the scaling down of groundwater development in the area. In the 1960s, few boreholes were drilled in the south-eastern corner of the System to provide potable water to communities which were displaced as a result of the 


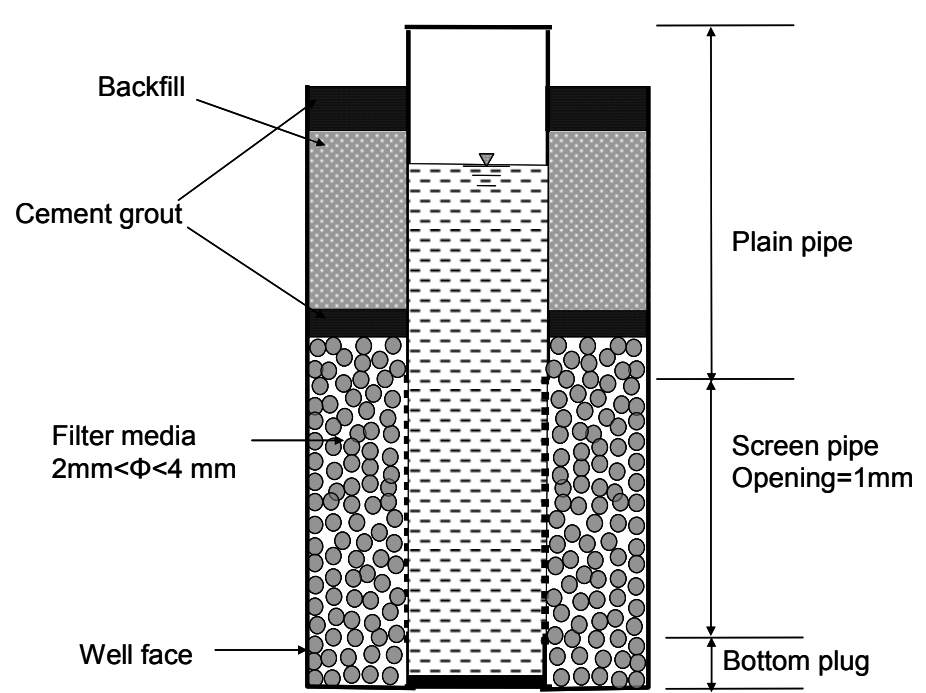

Figure 2(a). Sketch of borehole construction in Ghana.

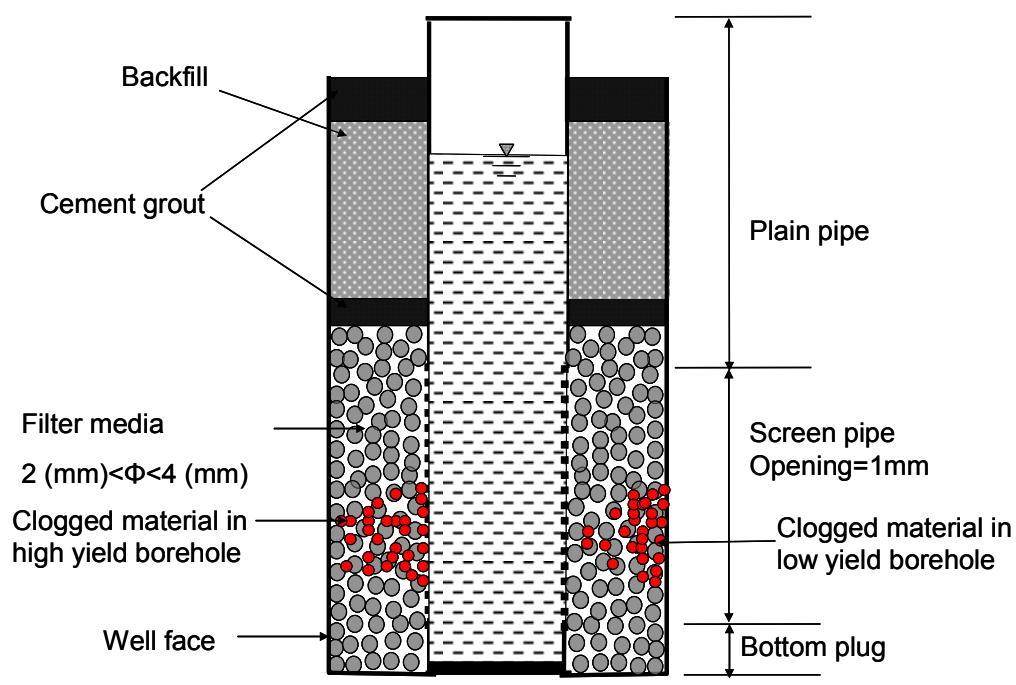

Figure 2(b). Sketch of filter clogging behind the screen.

construction of the Volta Lake [19]. In the mid 1970s, the Canadian International Development Agency (CIDA) entered the north-eastern end of the System to provide boreholes fitted with hand pumps. Based on the experiences gained from those previous drilling, the development of groundwater increased tremendously from the beginning of the 1980s. Within the last two decades many Non Governmental Organizations (NGOs), such as World Vision International, Water Aid, Church of Christ, European Union (EU), United Nations Children's Fund (UNICEF) and CIDA have been carrying out drilling operations in the System. There have been tremendous improvements in the drilling and development technology, and a complete change of siting boreholes using the traditional terrain evaluation to integrated terrain evaluation with geophysical surveys. However, due to the complex nature of the geology, the drilling success rates are still low, estimated to be about $50 \%$ with some of the already existing boreholes drying up [7,18,19,29,34].

\section{Borehole Construction}

Boreholes completed in the Voltaian Systems are lined with PVC pipes of about $140 \mathrm{~mm}$ diameter. Previously, stainless steel was also used to construct the boreholes but since the inception of Community Water and Sanitation Division (CWSD) in 1994, PVC is the only type of pipes used. In the aquifer zone, a screen is placed to allow inflow of groundwater into the borehole. The annular space (usually $50 \mathrm{~mm}$ ) between the borehole face and the PVC screen pipe is filled with filter media up to a few meters above the screen height. Figure 2(a) shows a schematic section of a lined borehole. Before a borehole would be considered for construction, it must meet a 
minimum yield of $13.5 \mathrm{l} / \mathrm{min}$ [35]. However, under difficult conditions, yields of at least $5 \mathrm{l} / \mathrm{min}$ are considered.

\section{Borehole Rehabilitation}

Boreholes drilled in the study area are usually community owned, handed over to them after the government or NGO drilling project is completed. It is the usual practice to train local personnel to maintain, repair and manage the boreholes. However, after the boreholes are handed over to beneficiary communities, there is a big issue of monitoring, maintenance and rehabilitation. This might pose a lot of threat to the sustainability of the boreholes as the people living in those communities lack the technology and funds to carry out such technical work [16]. Clogging may then set in with time if the fine particles within the filter material and the slots of the screens are not dislodged regularly.

\section{Clogging of Filters}

Clogging is a phenomenon that leads to reduction in available pores for fluid flow and resulting in reduction in permeability [36-38]. The cause of clogging could be chemical, biological or physical otherwise known as particle clogging. In the study area, there has neither been any reported case of chemical precipitation leading to chemical nor any case of biological clogging. For the purpose of this paper, the latter is discussed. Generally, particle and water inflows into boreholes are sieved through filters which can accommodate the fines for some time. If the fines are accumulated for a very long time they tend to block the inter-granular pores within the filter media. Although the inflow into the well may not change, the clogged filter media block the groundwater from flowing into the borehole. The end result may be the drying of the borehole. The early days of clogging in boreholes might not be easy to observe especially if the pump installed has a capacity far less than the actual borehole yield. In many cases, borehole cameras are installed to assess clogging. However, this may not show clogging between the filter and the face of the borehole as shown in Figure 2(b). Images from the cameras may only show clogging between the screen holes and the filter media. In this regard, numerical models are required to predict the clogging so that early remediation techniques can be applied.

\section{Filter Media for Borehole Construction}

Field monitoring on some boreholes in the far northwestern and north-eastern corners of the Voltaian System was conducted [13]. They monitored the yearly static water levels in 9 boreholes in the north-western and 10 in the north-eastern parts of the study area for 3 years. The authors concluded that the yearly falling water levels in the boreholes were as a result of over-use of groundwater. However, their results, in addition to static water levels from newly drilled boreholes during the monitoring period, suggested that the drying of boreholes may not be due to lowering of groundwater levels or over-use but other uninvestigated factors such as clogging.

It was observed and reported in literature that irrespective of the geological formation and aquifer material composition, the filter media used for borehole construction were the same in size [16].

As a part of efforts to determine the suitability of filter media used for borehole construction, both mathematical formulations and laboratory observations were made $[39,40]$. The filter pores were critically examined under the microscope to understand the distribution of the pores within the filter media. The authors compared the pore sizes of filters made from natural river sand and modified soil with cement. The pores were examined by compacting separately (filter media passed through sieves between 2 and $4.7 \mathrm{~mm}$ sizes) the two types of filters in cylindrical moulds. The samples were impregnated with resin and thin sections taken for microscopic observations (Figures 3(a) and 3(b)).

The results of the microscopic studies are shown in Table 1. The observations showed that the modal pores of the filter media from the river sand were tinny compared with the average pore size. The size of the modal pores of the modified filter was about three times the modal pore size for fluid flow in the natural river sand filter media.

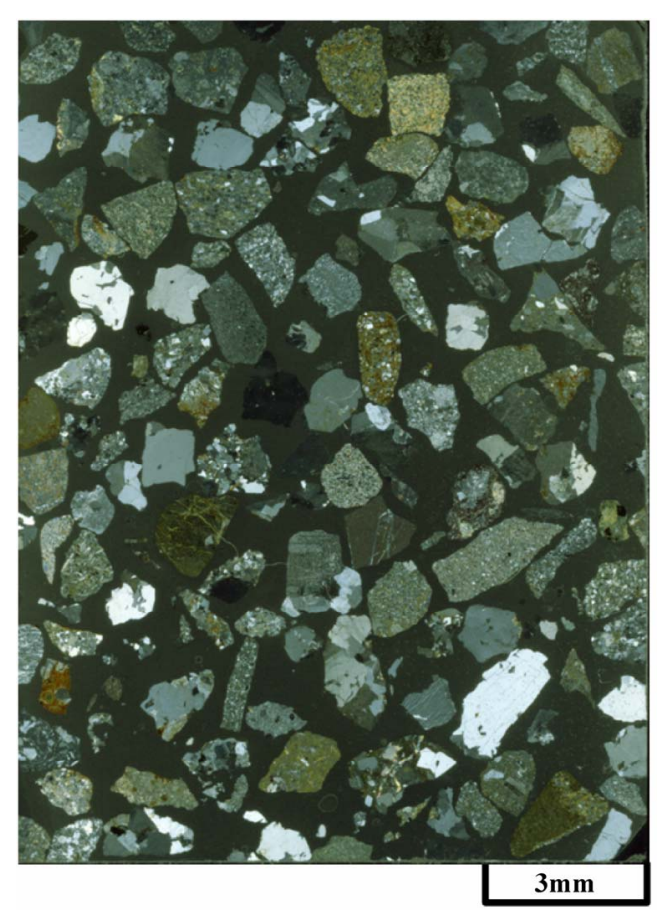

(a) River sand filter 


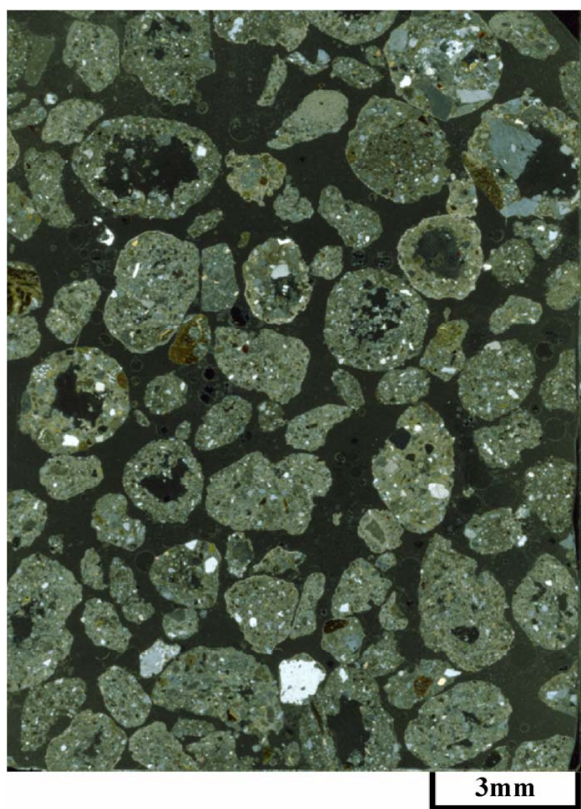

(b) Modified soil filter

Figure 3. Thin section of filter media (2-4.7 mm grain size [40]).

\section{Groundwater Coverage and Depletion}

Groundwater tapped from aquifers of the Voltaian is the main source of potable water supply for domestic purposes for most communities within the area. It was estimated that about $54.2 \%$ of the people depend on groundwater [41]. Tamale municipality and many other communities located close to the Lake Volta, totaling about $45.8 \%$ of the population, however, do not depend on groundwater for domestic purposes. Though the area under study covers about $40 \%$ of the land area of Ghana, the population density is very small. Figure 4 shows the estimated number of people living in areas covered by the Voltaian System [41,42]. It is estimated that about 1.83 million people would have been extracting groundwater from the Voltaian as at 2008. On an average, domestic water consumption is about 25 to $50 \mathrm{l} /$ person/day $[4,7,22]$. The total annual groundwater volume exploited for domestic use could rise to $3.34 \times 10^{7} \mathrm{~m}^{3}$ in the future. The groundwater recharge from rainfall has been investigated and ranges from 3.7 to $5 \%$ of annual rainfall. Rainfall data on the study area for the years 2000 to 2005 varies from 769.5 to $1101.5 \mathrm{~mm}$. Groundwater recharge from rainfall in 2005 would have been 28.5 to $38.5 \mathrm{~mm}$. The total volume of groundwater stored in the System will have been $2.96 \times 10^{9}$ to $4.00 \times 10^{9} \mathrm{~m}^{3}$. Despite the fact that groundwater abstraction is less than $1 \%$, the rate of failure of boreholes is high.

Borehole operation survey indicated that out of 492 boreholes, $13 \%$ of them had failed within the first 7 years after construction [7]. Though $8.5 \%$ of the failure was attributed to pump breakdown, the remaining $4.5 \%$ indicated lack of water in the borehole. A relation was reported between borehole drying, yield and the season when it was drilled. Figures 5 and 6 show the relationships between dried boreholes, yield and season of drilling.

Table 1. Summary of results from microscopic study [40].

\begin{tabular}{ccc}
\hline Filter type (between 2mm and 4.7mm particle size) & River sand & Modified soil \\
\hline Average microscopic pore size (mm) & 0.98 & 1.02 \\
Numerically determined average pore size $(\mathrm{mm})$ & 1.04 & 1.04 \\
Modal pore size $(\mathrm{mm})$ & 0.38 & 0.96 \\
\hline
\end{tabular}

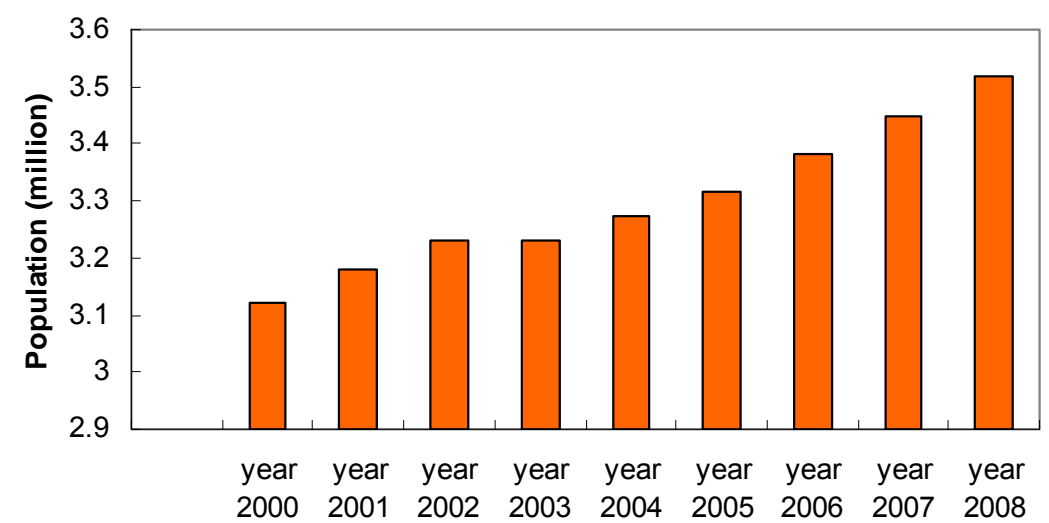

Figure 4. Estimated population living in areas covered by the Voltaian System. 


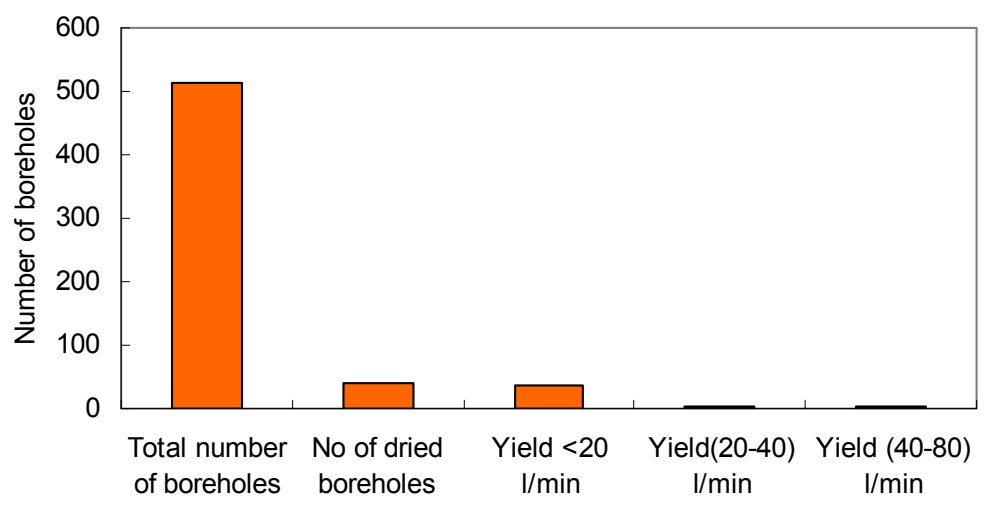

Figure 5. Relation between yield and drying of boreholes.

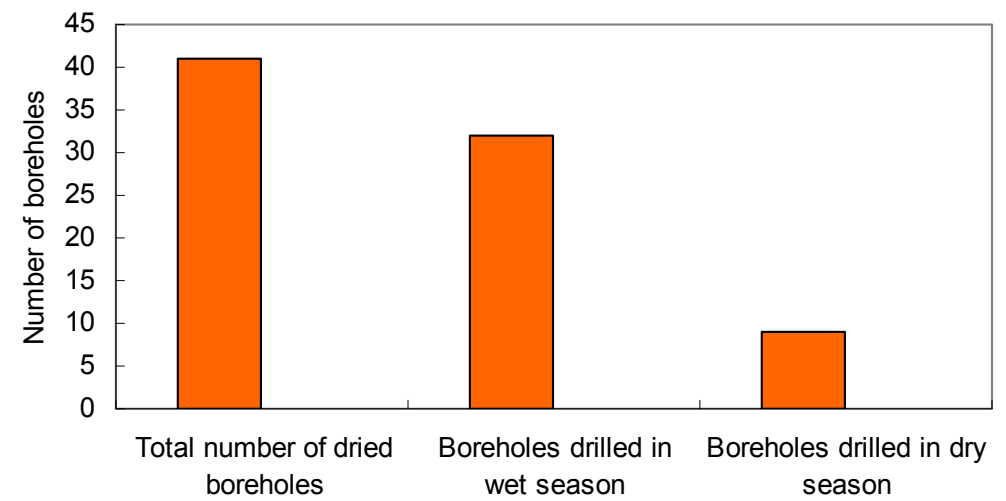

Figure 6. Relation between borehole drying and drilling season (wet season: July to February, Dry season: March-June).

\section{Discussions}

Borehole drying is a worldwide issue that needs serious attention. As reported in Mali, lack of confidence on the sustainability of boreholes has made women to prefer surface water [6]. Over $90 \%$ of boreholes in Mali were observed to be nonfunctional after one year of completion [8]. Similar reports have been read from South Africa, Uganda, Nigeria and many other African countries [9,16,43]. Borehole drying is a global problem especially in Africa. Regional aquifer heterogeneity might be one of the main causes of the drying. It is reported that over half the annual renewable groundwater supplies in Sub-Saharan Africa are located within only Democratic Republic of Congo, Republic of Congo, Cameroon and Nigeria [44].

In Ghana, the study area has low population density compared with other areas, and depends mainly on groundwater exploited through boreholes. Groundwater is extracted and used mainly for domestic purpose. Field observation in the study area has shown that drying boreholes are generally of low yields at the time of drilling (Figure 5). Boreholes with yields of less than 20 $1 /$ min are usually the worst affected. The current research has shown that about $63.4 \%$ of the boreholes found to be dried up had drill yields less than $20 \mathrm{l} / \mathrm{min}$.

Drilling programmes are usually time bound, and this influences the rate and season that boreholes are completed. Yields estimated in the wet seasons are normally not reflective of the actual aquifer condition since they might have become saturated. Figure 6 shows that about $78 \%$ of the dried boreholes were drilled in the wet season (from July-February). It is generally designed that a borehole should serve about 250 people with daily water need of 25 l/day [4,5]. This implies that a minimum of $8.7 \mathrm{l} / \mathrm{min}$ should be required as a standard for a newly drilled borehole to be considered for construction and use. However, to account for water loses and other unforeseen circumstances, a higher minimum yield has been set nationwide to be $13.5 \mathrm{l} / \mathrm{min}$ [35].

Quantitative recharge studies conducted in the area showed that total extraction is less than $5 \%$ of the estimated recharge $[22,23]$ which also supports the findings from isotopic studies conducted earlier [19,21]. From Figure 4, the highest water demand was estimated to be $3.34 \times 10^{7} \mathrm{~m}^{3}$ in the year 2008. Assuming the recharge from rainfall is $28.5 \mathrm{~mm}$ and only $30 \%$ of stored water is available for use, about $8.88 \times 10^{8} \mathrm{~m}^{3}$ could be exploited. In this regard, only $3.8 \%$ of stored water would have been used, thus confirming the results of previous researches which suggest that there is enough recharge. Interestingly, new boreholes drilled closer to some dried 
boreholes have always shown static water levels equal to the initial water levels of the dried boreholes, although the existing water levels in the dried boreholes are far below expectation. This further suggests that the drying is not due to depletion of groundwater, as intimated by workers such as $[22,23,32,33]$. However, availability of enough groundwater reserve does not necessarily mean boreholes cannot dry up. Aquifer heterogeneity can also cause the drying. For hand pump, only 6 hour pumping test is conducted which might not be enough to stretch the aquifer to its limits. Besides this, the pumping tests are carried out on single boreholes which are not usually reliable. The aquifer properties such as storativity and transmissivities might not be accurately estimated especially as most aquifers are located in fractured rock environments.

Borehole construction errors could also be a possible source of the drying issues. When boreholes are constructed, they are normally constructed with plain and screen pipes, and filter media walled around the screen as shown in Figure 2(a). Defective screen and plain pipes could lead to siltation that could block transmission. To ensure good filtering, a filter classification proposed by [45] is suitable for use. The classification requires that $D_{15} / d_{85}<4$ should be satisfied, where $D_{15}$ means $15 \%$ by mass of the filter particles are finer than that size and $85 \%$ of the particles are finer than $d_{85}$ particle size of the base material. Although many researchers have opposed the numerical value and particle size pertaining to the filter use [46-48], the ratio serves as a good guide to filter selection. However, it is highly impossible to obtain all the fines during drilling especially in the case of saturated aquifer. Consequently, in borehole construction, a general classification based on certain filter size range is usually prescribed by the local authorities controlling borehole development. For example, filter size ranging from 2-4 $\mathrm{mm}$ has been recommended for all boreholes drilled in Ghana by the Community Water and Sanitation Agency (CWSA). The performance of the filter depends on its pore size and the type of fine sediments found in the incoming groundwater at the filter media-borehole interface.

As mentioned earlier, microscopic studies on similar filter material from a natural river source prescribed by CWSA showed that the average pore size was $0.98 \mathrm{~mm}$ and the modal pore size available for fluid flow was $0.38 \mathrm{~mm}$ [40]. However, results from the modified filter showed that there were nearly equal average and modal pores of $1.02 \mathrm{~mm}$ and $0.96 \mathrm{~mm}$, respectively for fluid flow (Table 1). The smaller modal pore sizes can easily get blocked by incoming dirt compared to the larger pore size.

Due to many human activities such as farming and charcoal burning, the land is exposed to erosion and, hence, during recharge especially in the fractured aquifer systems, fines enter the fractures. These sediments may be trapped by the filter media upon entering the borehole face. Although seemly conceptual, as groundwater enters the borehole face the velocity increases, and the change in velocity could cause transportation or deposition of finer material or repositioning of particles of the filter media. Since the filter media is usually of very small radial thickness ranging from about 5 to $10 \mathrm{~cm}$ or a little more, particles are capable of being pushed through if the force with which they travel is high. In this regard, boreholes with higher yields are capable of providing enough force than low yielding ones. It has been reported that fluid velocity controls particle penetration into porous media and that higher velocities mean farther distance of transportation and deposition [36,38]. In muddy environments, the slurry can be pushed into the borehole or stick around the space between the filter media and the borehole screen. In such situations, it is easy to suck the dirt into the borehole during pumping.

In relatively low yielding boreholes, the entrance force of flowing slurry might not be too high thereby resulting in the deposition of the mud and fines around the point of entrance into the filter media. Continual deposition of the fines leads to clogging and cementation of the filter pores. As the deposition continues, the inflow of groundwater into the borehole is almost blocked. In such case, the water level in the borehole may fall below the general groundwater level as water is drawn from the stored water by the users without replenishment.

Clogging in low yielding boreholes might start from the area between the well face and that of the filter towards the well screen, whereas, those of high yielding may start from between the screen and the filter backwards (Figure 2(b)). In this regard, it is very common to find low yielding boreholes having been redeveloped but no water comes out. The cleaning exercise might not be effective to dislodge the clogged material in the far side of the filter-well surface. On the other hand, because of the proximity of the clogged material to the screen in high yielding boreholes, early cleaning intervention such as rehabilitation may be very effective. This may explain why some low yielding boreholes tend to fail even if attempts are made to clean them.

During pumping, the deposition of fine particles flowing with groundwater into the filter media depends much on the velocity with which they travel and filter pore size. If the weights of the individual fine particles in the flowing water are greater than the forces pushing them in motion, the particles may suddenly come to rest and obstruct the movement of much lighter ones even if their sizes are smaller than the pores in the filter media. If the drag forces are higher and the particles are smaller, then, they may be transported through pores of the filter without deposition. Due to the clayey nature of the rocks in the Voltaian System, the swelling of these particles are 
possible if the particles are not quickly pushed through the pores of the filter media.

Generally around the borehole face of a low yielding borehole, the velocity of incoming fines cannot be compared with those of high yields. Assuming that all the boreholes of variable yields are located in the same geologic aquifer rich in clay particles, and the same fine particles are found in the inflowing water, then, the low yielding boreholes will quickly get clogged. Filter media clogging could therefore be contributing to the depletion of the water in the boreholes as inflow is adversely affected. Clogging in low or marginal yield boreholes are easy to observe because the yield diminishes abruptly unlike the high yielding ones whose may still match the flow rates of the hand pump for a very long time. Frequent monitoring of the boreholes is therefore very important so that beneficiary communities can be advised.

\section{Conclusions and Recommendations}

1) Borehole drying is a worldwide issue especially in Sub-Sahara Africa.

2) Drying of marginal or low yielding boreholes in clay rich sediment environments such as the Voltaian System in Ghana affects borehole sustainability and water supply.

3) Borehole drying has a relation with yield and season in which drilling was completed.

4) The review suggests that filter clogging could be a possible cause of the drying of the boreholes. Although many researches have been carried out, not much has been done in relation to clogging especially filter clogging.

5) The type of filter media used in Ghana has smaller modal pore sizes. These sizes can easily be blocked by clay and finer particles.

6) The authors recommend that further work be done to measure the fines transported with groundwater in the area and to select the appropriate size of filter media for the construction of boreholes.

7) Marginal boreholes also need to be rehabilitated regularly to help reduce or dislodge clays and other particles from clogged filter media before cementation.

8) Drilling projects should consider the dry season as most appropriate period for drilling and borehole yield estimation.

\section{Acknowledgements}

The authors wish to acknowledge the anonymous reviewer for his critics that have contributed to improving this paper.

\section{References}

[1] J. Kirchner, J. H. Moolman, H. M. du Plessis, and A. G. Reynders, "Causes and management of salinity in the Breede River Valley, South Africa,” Hydrogeology J. Vol. 5, No. 1, pp. 98-108, 1997.

[2] L. Changing and Z. Shifeng, "Drying up of the yellow river: its impacts and counter-measures,” Mitigation and Adaptation Strategies for Global Chang, Vol. 7, pp. 203-214, 2003.

[3] DFID, “Addressing the water crisis: Healthier and more productive lives for poor people, strategies for achieving the international development targets,” Department for International Development, UK, 2001.

[4] A. M. MacDonald, J. Davies, and B. Dochartaigh, "Simple methods for assessing groundwater resources in low permeability areas of Africa,” British Geological Society, Nottingham, UK, 2002.

[5] S. B. O. Jallow, 4th World Water Forum, Mexico, 2008. http://www.bvsde.ops-oms.org/bvsacg/e/foro4/19\%20mar zo/Water/RWSSI.pdf.

[6] B. A. Gleitsmann, M. M. Kroma, and T. Steenhuis, "Analysis of a rural water supply project in three communities in Mali: Participation and sustainability,” Natural Res. Forum, Vol. 31, pp. 142-150, 2007.

[7] P. A. Harvey, "Borehole sustainability in rural Africa: An analysis of routine field data," People-Centred Approaches to Water and Environmental Sanitation in 30th WEDC International Conference, Vientiane, Lao PDR, 2004.

[8] World Bank, Performance Audit Report No. 16511, World Bank, Washington DC, 1997.

[9] D. Hazelton, "The development of community water supply systems using deep and shallow well handpumps," Water Research Centre (WRC ) Report No. TT132/00, South Africa, 2000.

[10] DWD, "Overview of the water sector, reform, SWAP and financial issues," Directorate of Water Development, Ministry of Water, Lands and Environment, Issue Paper 1, The Republic of Uganda, 2002.

[11] P. A. Harvey and R. A. Reed, "Rural water supply in Africa: Building blocks for handpump sustainability," WEDC, Loughborough University, UK, 2004.

[12] D. E. Kromm and S. E. White, "Groundwater problems," In: D. E. Kromm, White S. E., (Ed.), Groundwater exploitation in the High Plains, University of Kansas Press, Lawrence, Kansas, pp. 44-63, 1992.

[13] J. A. Ayamsegna and P. Amoateng-Mensah, "Well monitoring: World Vision's experience in Ghana,” in 28th WEDC Conference on Sustainable Environmental Sanitation and Water Services, Kolkata (Calcutta), India, 2002.

[14] M. R. Llamas and P. Martinez-Santos, "Ethical issues in relation to intensive groundwater use,” In M. R. Liamas., E. Custoddio (Ed.), Intensive Use of Groundwater Challenges and Opportunities, Balkema Publishers, The Nertherlands, pp. 3-22, 2005. 
[15] J. Samper, "Intensive use of groundwater in the European Union Water Framework Directive,” In: A. Sahuquillo, J. Capilla, L. Martinez-Cortina, X. Sanchez-Vila, (Ed.), Groundwater Intensive Use, A. A Balkema Publishers, Leiden, the Nertherlands, pp. 93-101, 2005.

[16] J. A. Akudago, K. Kankam-Yeboah, L. P. Chegbeleh, and M. Nishigaki, "Assessment of well design and sustainability in hard rock systems of northern Ghana," Hydrogeology J., Vol. 15, pp. 789-797, 2007.

[17] Water Treatment, 2008. http://www.who.int/water_sanitation_health/hygiene/om/linkingchap6.pdf.

[18] S. Y. Acheampong, D. Owusu, P. Gyau-Boakye, and N. B. Ayibotele, "Groundwater utilization in the Afram Plains,” International Report, Water Resources Research Institute, Council for Scientific and Industrial Research, Accra, 40pp, 2005.

[19] A. J. E. Cobbing and J. Davies, "Understanding problems of low recharge and low yield in boreholes: An example from Ghana,” In: D. Stephenson, E.M. Shemang, T. R. Chaoka (Ed.), Water resources of arid areas, A. A Balkema Publishers, London, UK, 2004.

[20] C. Anani, "Sandstone petrology and provenance of the Neoproterozoic Voltaian Group in the southeastern Voltaian Basin, Ghana," Sedimentary Geol., Vol. 128, pp. 83-98, 1999.

[21] S. Y. Acheampong and J. W. Hess, "Origin of the shallow groundwater system in the Southern Voltaian Sedimentary basin of Ghana: An isotopic approach,” J. Hydrol., pp. 233, 37-53, 2000.

[22] N. Martin and N. van de Giesen, "Spatial distribution of groundwater production and development potential in the Volta River basin of Ghana and Burkina Faso," Water Int., Vol. 30, No. 2, pp. 239-249, 2005.

[23] A. Lutz, J. M. Thomas, G. Pohll, and W. A. McKay, "Groundwater resource sustainability in the Nabogo Basin of Ghana,” J African Earth Sci., Vol. 49, pp. 61-70, 2007.

[24] C. A. Kwei, "Evaluation of groundwater potential in the northern region of Ghana," Canadian International Development Agency (CIDA), Accra, Ghana, 1997.

[25] G. O. Kesse, "The mineral and rock resources of Ghana," A. A Balkema, Rotterdam, 1985.

[26] G. Limited, "Hydrogeological study for borehole siting, training and methodology. 350 Borehole programme in Yendi and East Mamprusi districts,” Northern Region Rural Integrated Programme, Ghana, 1991.

[27] L. P. Chegbeleh, J. A. Akudago, M. Nishigaki, and S. N. K. Edusei, "Electromagnetic geophysical survey for groundwater exploration in the Voltaian of northern Ghana”, J. Environmental Hydrology, Vol. 17, Paper 9, 2009.

[28] P. S. GMBH, “The 30 well drilling project,” Internal Report, Catholic Diocese of Accra, 1984.
[29] P. K. Darko, "Prevailing transmissivity of hard rocks in Ghana,” J The Ghana Sci. Assoc., Vol. 2, No. 2, pp. 26-35, 2002.

[30] D. K. Buckley, "Report on advisory visit to water aid projects in Ghana," Unpublished Report, British Geological Survey, Hydrogeology Research Group, Wallingford, 1986.

[31] W. B. Apambire, D. R. Boyle, and F. A. Michel, "Geochemistry, genesis and health implications of fluoriferous groundwaters in the upper regions of Ghana,” Environmental Geol., Vol. 33, No. 1, pp. 13-24, 1997.

[32] J. Ricolvi, "Selected case studies: Burkina Faso,” In: J. Llyod, (Ed), Water Resources of Hard Rock Aquifers in Arid and Semi-Arid Zones, Paris, United Nations Educational, Scientific, and Cultural Organization, pp. 262-275, 1999.

[33] W. Apambire, "Geochemical modeling and geomedical implications of fluoriferous groundwaters in the upper east region of Ghana,” Unpublished Dissertation, University of Nevada, Reno, 2000.

[34] S. Dapaah-Siakwan and P. Gyau-Boakye, "Hydrogeologic framework and borehole yields in Ghana," Hydrogeology J., Vol. 8, pp. 405-416, 2000.

[35] Community Water and Sanitation Division of Ghana Water and Sewerage Corporation, "National community water and sanitation programme, policy, strategy and guide lines,” Accra, Ghana, 1996.

[36] S. Veerapaneni and M. R. Wiesner, "Deposit morphology and head loss development in porous media”, Environmental Sci. and Tech., Vol. 31, pp. 2738-2744, 1997.

[37] S. Ishida, M. Kotoku, E. Abe, M. A. Fazal, T. Tsuchihara, and M. Imaizumi, "Construction of subsurface dams and its impact on the environment," In: International Conference on Groundwater in Geological Engineering, Bled, Slovennia, September 2003.

[38] D. C. Mays and J. R. Hunt, "Hydrodynamic aspects of particle clogging in porous media," Environmental Sci. and Tech., Vol. 39, pp. 577-584, 2005.

[39] J. A. Akudago, M. Nishigaki, L. P. Chegbeleh, M. A. Alim, M. Komatsu, and K. Kumamaru, "State of the art on filter design and particle clogging; and proposed new numerical approach to redesign,” J. Faculty of Environmental Sci. and Tech. Okayama University, Japan, Vol. 13, pp. 63-66, 2008.

[40] J. A. Akudago, M. Nishigaki, L. P. Chegbeleh, M. A. Alim, and M. Komatsu, "Filter choice and its relation to well construction and sustainability in rural water supply," In: Proceedings of the 36th Congress of International Association of Hydrogeolosist, Toyama, Japan, October 26-November 2, 2008.

[41] Ghana Statistical Services, "Summary report of final results, 2000 population and housing census,” Ghana Statistical Services, Accra, Ghana, 2002.

[42] CIA World Fact Book, 2008. http://indexmundi.com/g/ g.aspx?c =gh\&v=2 "Personal communication," Depart- 
ment of Geology and Mineral Sciences, University of Ilorin, Nigeria.

[43] S. M. A. Adelana, Personal Communication, Department of Geology and Mineral Sciences, University of Ilorin, Nigeria.

[44] M. Giordano, “Agricultural groundwater use and rural livelihoods in sub-Saharan Africa: A first-cut assessment,” Hydrogeology J., Vol. 14, pp. 310-318, 2006.

[45] K. Terzaghi and R. Peck, "Soil mechanics in engineering practice,” John Wiley and sons Inco., New York, 1948.

[46] T. Kenney, R. Chachal, E. Chiu, G. Ofoegbu, G. Omange, and C. A. Ume, "Controlling constriction sizes of granu- lar filters,” Canadian Geotechnical J., Vol. 22, No. 1, pp. 32-43, 1985.

[47] B. Indraratna and A. K. Raut, "Enhanced criterion for base retention in embankment dam filters," J Geotechical and Geoenvironmental Engg., pp. 1621-1627, ASCE December 2006.

[48] J. L. Sherard, L. P. Dunnigan, and J. R. Talbot, "Basic properties of sand and gravel filters,” J. Geotechnical Engg., Vol. 110, No. 6, pp. 684-700, 1984. 